\title{
Prevalensi dan Faktor Risiko Anemia pada HIV-AIDS
}

\author{
Rachmat Sumantri, ${ }^{1}$ Rudi Wicaksana, ${ }^{1}$ Agnes R. Ariantana ${ }^{2}$ \\ ${ }^{1}$ Bagian Ilmu Penyakit Dalam, ${ }^{2}$ Bagian Patologi Klinik Fakultas Kedokteran Unpad \\ Tim Penanggulangan AIDS Rumah Sakit Hasan Sadikin, Bandung
}

\begin{abstract}
Abstrak
Anemia berperan dalam morbiditas dan mortalitas penderita HIV-AIDS. Penelitian mengenai anemia pada infeksi HIV di Indonesia belum banyak. Studi potong lintang dilakukan untuk mengetahui prevalensi dan faktor risiko anemia pada penderita HIV-AIDS di Poliklinik Teratai RS. Hasan Sadikin dari 1 Januari-30 Juni 2008. Hasil penelitian: terdapat 534 penderita HIV-AIDS, anemia 222 penderita, prevalensinya 41,6\%. Anemia ringan (Hb 10$14 \mathrm{~g} / \mathrm{dL}$ laki-laki, 10-12 g/dL wanita) didapatkan pada 188 penderita (35\%); anemia sedang (Hb 8-10 g/dL) pada 28 penderita $(5,2 \%)$, dan anemia berat $(\mathrm{Hb}<8 \mathrm{~g} / \mathrm{dL})$ terdapat pada 6 penderita $(1,1 \%)$. Faktor risiko yaitu jenis kelamin, umur, indeks massa tubuh (BMI), intravenous drug user (IDU), stadium klinis WHO, kandidiasis oral, peradangan kronik, pemberian kotrimoksazol, pemberian ARV, tuberkulosis, CD4, dan viral load. Uji statistik menunjukkan bahwa faktor risiko anemia yang penting adalah BMI antara 18,5-22,9 dengan OR 0,368 (95\% CI 0,216-0,627). Kandidiasis oral dengan OR 1,793 (95\% CI 0.99-3,248), pemberian ARV dengan OR 0,905 (95\% CI 0,555-1,474), dan CD4 antara 1-50 dengan OR 8,66 (95\% CI 4,407-13,522). Peluang kejadian terbesar untuk kejadian anemia adalah kombinasi BMI yang rendah $(<18,5)$ baik mendapat ARV ataupun tidak mendapat ARV dengan kandidiasis

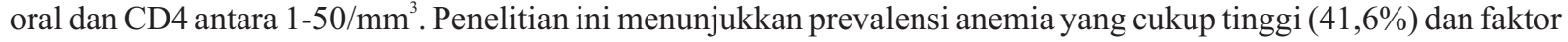
risiko yang penting untuk kejadian anemia adalah BMI yang rendah, kandidiasis oral, ARV dan CD4 yang rendah. [MKB. 2009;41(4):187-93].
\end{abstract}

Kata kunci: HIV-AIDS, anemia, faktor risiko

\section{Prevalence and Risk Factors of Anemia in HIV-AIDS}

\begin{abstract}
Anemia has an important role in morbidity and mortality among HIV-AIDS patients. The study of anemia among HIV-AIDS patients in Indonesia was not much done. A cross-sectional study has been done in Teratai Clinic Hasan Sadikin Hospital Bandung to evaluate the prevalence and risk factors of anemia in HIV-AIDS patients between 1 January to 30 June 2008. There were 534 HIV-AIDS patients, anemia occured in 222 patients, the prevalence was $41.6 \%$. Mild anemia or $\mathrm{Hb}$ level $10-14 \mathrm{~g} / \mathrm{dL}$ in man or $10-12 \mathrm{~g} / \mathrm{dL}$ in woman was found in $188(35 \%)$, moderate anemia or $\mathrm{Hb} 8-10 \mathrm{~g} / \mathrm{dL}$ in $28(5,2 \%)$ and severe anemia or $\mathrm{Hb}$ less than $8 \mathrm{~g} / \mathrm{dL}$ in $6(1,1 \%)$ patients. Risk factors were gender, age, BMI, IDU, WHO staging, oral candidiasis, chronic inflammation, ARV, tuberculosis, CD4, and viral load. Statistical analysis showed that the important risk factors were BMI between 18.5-22.9 OR 0.368 (95\% CI 0.216-0.627), oral candidiasis OR 1.793 (95\% CI 0.99-3.248), use of ARV OR 0.905 (95\% CI 0.555-1.474), and CD4 1-50 OR 8.66 (95\% CI 4.407-13.522). The chance of anemia was great in combination of BMI $\leq 18.5$ with CD4 $\leq 50$, oral candidiasis with or without ARV. This study showed that the prevalence of anemia in HIV-AIDS patients is prominent and the important risk factors for anemia are BMI, oral candidiasis, ARV and CD4.
\end{abstract}

[MKB. 2009;41(4):187-93].

Key words: HIV-AIDS, anemia, risk factors

\footnotetext{
Korespondensi: Rachmat Sumantri, dr., SpPD-KHOM, Bagian Ilmu Penyakit Dalam, Fakultas Kedokteran Universitas Padjadjaran, Rumah Sakit Hasan Sadikin, Jln Pasteur No. 38 Bandung 40161, Telp. (022) 2034545, Hp. 0811218393, Email:rsumantri@yahoo.com
} 


\section{Pendahuluan}

Infeksi oleh human immunodeficiency virus (HIV) yang menyebabkan AIDS (autoimmune deficiency syndrome) mulai dikenal sejak tahun 1983. Sampai akhir tahun 2007 sudah menyebabkan infeksi 33,2 juta penduduk dunia dan menyebabkan kematian 2,1 juta penduduk. Menurut WHO istilah AIDS dipergunakan pada penderita infeksi HIV dengan jumlah CD4 di bawah 200/ $\mathrm{mm}^{3}$. CD4 adalah sel limfosit-T (T-helper) yang diserang dan dihancurkan oleh virus HIV, dan jumlah virus HIV di dalam tubuh manusia disebut viral load. Penderita infeksi HIV terbanyak di dunia yaitu di Afrika disusul oleh Asia dan Amerika Serikat. Pada tahun 2007 terdapat 2,5 juta kasus infeksi HIV baru, angka ini naik sebesar 15\% dari tahun 2001, saat itu United Nations Programme on Aqcuired Immune Deficiency Syndrome (UNAIDS) melaporkan 29 juta penduduk dunia terinfeksi HIV dengan 1,7 juta kematian. $^{1,2}$

Penyakit ini mulai dikenal di Indonesia pada tahun 1987, sejak itu jumlah penderita HIV-AIDS di Indonesia terus meningkat. Sampai dengan akhir Desember 2008 telah terjadi peningkatan jumlah kasus menjadi 22.664 terdiri dari 16.110 kasus AIDS dan 6.554 kasus infeksi HIV belum dinyatakan sebagai AIDS. ${ }^{3}$ Laporan akhir tahun 2008 menunjukkan Jawa Barat menduduki peringkat teratas dari jumlah kasus infeksi HIV disusul oleh DKI Jakarta, Jawa Timur, kemudian Papua. ${ }^{3,4}$ Di Jawa Barat menurut laporan P2M Dinas Kesehatan Provinsi Jawa Barat sampai dengan September 2008 terdapat 4.422 kasus infeksi HIV, sebanyak 2.593 kasus di antaranya dengan AIDS. ${ }^{5}$ Di Poliklinik Teratai Rumah Sakit Hasan Sadikin Bandung sejak Desember 1996 sampai akhir 2008 tercatat 1.593 kasus infeksi HIV, 1.009 kasus di antaranya adalah AIDS, dan 496 penderita aktif menggunakan ARV. Sebanyak $68,9 \%$ penderita adalah pengguna narkoba suntik intravenous drug user (IDU).

Prevalensi anemia pada infeksi HIV cukup tinggi, berkisar antara 1,3\% - 95\% tergantung dari stadium penyakitnya. Makin lanjut penyakitnya sehingga kejadian anemia juga makin tinggi dan meningkatkan morbiditas serta mortalitas. ${ }^{6,7}$ Hasil dari meta analisis oleh Belperio dan Rhew ${ }^{6}$ memperlihatkan bahwa anemia merupakan faktor risiko independen untuk kematian pada HIVAIDS, di samping jumlah CD4 dan viral load.
Penelitian anemia pada HIV-AIDS di Indonesia belum terlalu mendalam, terbukti dari kurangnya makalah yang mengupas anemia pada HIV-AIDS. Lydia ${ }^{8}$ di Jakarta melaporkan kejadian anemia sebanyak $100 \%$ pada 33 penderita AIDS di Rumah Sakit Umum Nasional Cipto Mangun kusumo antara bulan November 1990-Februari 1996. Pada tahun 2002, Surzamin ${ }^{9}$ melaporkan 115 penderita AIDS yang pernah dirawat di tempat yang sama terdapat anemia pada $60,2 \%$ kasus. Fauzan dkk. ${ }^{10}$ di RSCM melaporkan kejadian anemia 7,2\% dengan batas anemia hemoglobin $10 \mathrm{~g} / \mathrm{dL}$. Efiyanti dkk.," melaporkan kejadian anemia pada 25\% kasus HIV-AIDS di Jakarta. Karyadi dkk., ${ }^{12}$ di Pokdisus AIDS RS. Cipto Mangun Kusumo Jakarta mendapatkan anemia pada $13,7 \%$ penderita yang mendapatkan zidovudin. Karsono dan Muthalib ${ }^{13}$ melaporkan bahwa $16,2 \%$ dari penderita HIV-AIDS yang mendapat zidovudin menderita anemia.

Penelitian ini bermaksud untuk mengetahui prevalensi anemia dan faktor risiko yang berperan dalam kejadian anemia pada penderita HIV-AIDS seperti umur, jenis kelamin, BMI (body mass index), IDU, stadium klinis WHO, peradangan kronik, zidovudin, kotrimoksazol, tuberkulosis, kandidiasis oral, CD4 dan viral load. Hasil dari penelitian ini diharapkan akan dapat membantu para klinisi untuk mengelola anemia pada penderita HIV-AIDS sebaik-baiknya.

\section{Metode}

Subjek penelitian ini adalah penderita HIV-AIDS yang berobat ke Poliklinik Teratai Rumah Sakit Hasan Sadikin Bandung dan penderita HIV-AIDS yang dirawat inap di Rumah Sakit Hasan Sadikin Bandung, Klinik Rumatan Metadon dan Lembaga Pemasyarakatan Banceuy, yang masuk dalam data basis Poliklinik Teratai RS. Hasan Sadikin sejak Januari sampai dengan 30 Juni 2008. Pada setiap penderita infeksi HIV dilakukan wawancara, pemeriksaan fisis, dan pemeriksaan laboratorium, antara lain pemeriksaan hematologi rutin, CD4 dan viral load. Penelitian dilakukan dengan memakai studi potong lintang. Semua subjek akan mendapatkan informasi terlebih dahulu tentang penelitian dan menandatangani surat persetujuan (informed consent) untuk mengikuti penelitian termasuk pencatatan data dan pengambilan sampel darah. Semua data dicatat pada formulir 
khusus yang telah dibuat.

Variabel yang digunakan untuk penelitian ini yaitu umur, jenis kelamin, indeks massa tubuh, IDU, stadium klinis WHO, peradangan kronik, zidovudin, kotrimoksazol, tuberkulosis, kandidiasis oral, CD4, dan viral load. CD4 diperiksa dengan flowcytometry, satuannya $\mathrm{sel} / \mu \mathrm{L}$, harga normal: 355-1.213 sel/uL. Viral load diperiksa di Laboratorium Kesehatan Daerah Provinsi Jawa Barat, pemeriksaan dilakukan dengan metode RTPCR (reverse transcryptasepolymerase chain reaction) menggunakan Cobasamplicor HIV-1 monitor version 1:5 (Roche). Pada Rentang pemeriksaan $400-750.000 \mathrm{kopi} / \mathrm{mm}^{3}$. Normal: virus tidak terdeteksi atau kurang dari 400 kopi/ $\mathrm{mL}$.

Definisi anemia yang dipergunakan adalah kadar hemoglobin untuk laki-laki $<14 \mathrm{~g} / \mathrm{dL}$ dan $<12 \mathrm{~g} / \mathrm{dL}$ untuk wanita. ${ }^{14}$ Anemia dapat dibagi menjadi anemia ringan bila $\mathrm{Hb}$ antara $10-12 / 14$ $\mathrm{g} / \mathrm{dL}$, anemia sedang $\mathrm{Hb}$ antara 7-10 g/dL dan anemia berat $\mathrm{Hb}$ kurang dari $7 \mathrm{~g} / \mathrm{dL}$.

Kriteria inklusi adalah semua penderita infeksi HIV-AIDS yang berobat di Rumah Sakit Hasan Sadikin dan Lembaga Pemasyarakatan Banceuy yang masuk ke dalam data basis di Poliklinik Teratai Rumah Sakit Hasan Sadikin dan bersedia mengikuti penelitian dengan menandatangani formulir kesediaan.

Dalam penelitian ini rancangan analisis yang dipergunakan yaitu untuk prevalensi anemia yang dinyatakan dalam persentase, dan dalam analisis statistik dinyatakan dengan proporsi melalui confidence interval. Sedangkan ukuran sampel yang diperlukan untuk analisis deskriptif dari prevalensi anemia digunakan rumus proporsi. Dengan memakai rumus proporsi dan presisi $5 \%$, maka ukuran sampel yang diperlukan yaitu 385 .

Analisis dilakukan dengan regresi logistik ganda. Ukuran sampel yang diperlukan untuk faktor risiko anemia dipergunakan rule of thumb, sehingga ukuran sampel untuk faktor risiko anemia adalah 240. Semua pekerjaan analisis data akan mempergunakan program komputer SPSS for windows versi 15.0

Penelitian dilakukan di Rumah Sakit Hasan Sadikin khususnya di Poliklinik Teratai dan Unit Penelitian Kedokteran - Program IMPACT.

\section{Hasil}

Penelitian tentang prevalensi anemia dan faktor risiko yang berperan pada penderita HIV-AIDS dilakukan terhadap 534 penderita yang masuk dalam data basis di Poliklinik Teratai RS Hasan Sadikin dari 1 Januari sampai 30 Juni 2008. Dari 534 penderita HIV-AIDS terdapat 222 penderita yang masuk dalam kategori anemia, atau besarnya prevalensi anemia pada penderita HIV-AIDS adalah 41,6\% (95\% CI: 37,4-45,8\%).

Dari sudut derajat anemia didapatkan sebanyak $312(58,4 \%)$ tidak anemia, $188(35,2 \%)$ penderita dengan anemia ringan, $28(5,2 \%)$ penderita anemia sedang dan $6(1,1 \%)$ penderita anemia berat.

Hubungan antara berbagai faktor risiko anemia sebagai faktor karakteristik atau variabel dengan kejadian anemia dapat dilihat pada Tabel 1 sampai Tabel 3 .

Dari Tabel 1 menunjukkan bahwa sebagian besar penderita adalah laki-laki untuk berbagai derajat anemia maupun untuk penderita HIVAIDS yang tidak anemia, dengan kisaran $75 \%$. Penderita HIV-AIDS dengan anemia menunjukkan BMI yang lebih rendah dibandingkan dengan kelompok penderita HIV-AIDS yang tidak anemia.

Dari Tabel 2 menunjukkan bahwa sebagian penderita HIV-AIDS di RS. Hasan Sadikin Bandung mempunyai riwayat IDU. Riwayat tuberkulosis terdapat pada $34,1-39,4 \%$ penderita, kelompok penderita dengan derajat anemia sedang berat mempunyai riwayat tuberkulosis lebih tinggi dari kelompok lainnya. Kandidiasis oral didapatkan lebih banyak pada penderita dengan stadium III dan IV, dan kandidiasis oral mempunyai nilai $\mathrm{p}(0,10)$ yang signifikan untuk

Tabel 1 Karakteristik Demografi Penderita HIV-AIDS dengan Anemia dan Tanpa Anemia

\begin{tabular}{lcccc}
\hline \multicolumn{1}{c}{ Variabel } & Tidak anemia & $\begin{array}{c}\text { Anemia ringan } \\
\mathbf{n}=\mathbf{3 1 2}\end{array}$ & $\begin{array}{c}\text { Anemia sedang-berat } \\
\mathbf{n}=\mathbf{3 4}\end{array}$ & Nilai $\mathbf{p}$ \\
\hline Laki-laki,\% & $231 / 312(74)$ & $142 / 188(75,5)$ & $25 / 34(73,5)$ & 0,92 \\
Umur, median (IQR) & $29(26-31)$ & $29(26-32)$ & $29(27-32)$ & 0,87 \\
BMI, median & $21,1(19,2-23,1)$ & $19,0(17,2-21,8)$ & $16,9(14,4-20,3)$ & $<0,001$ \\
\hline
\end{tabular}


Rachmat Sumantri: Prevalensi dan Faktor Risiko Anemia pada HIV-AIDS

Tabel 2 Karakteristik Klinis Penderita HIV-AIDS dengan Anemia dan Tanpa Anemia

\begin{tabular}{lcccc}
\hline \multicolumn{1}{c}{ Variabel } & $\begin{array}{c}\text { Tidak Anemia } \\
\mathbf{n}=\mathbf{3 1 2}\end{array}$ & $\begin{array}{c}\text { Anemia Ringan } \\
\mathbf{n = 1 8 8}\end{array}$ & $\begin{array}{c}\text { Anemia Sedang-Berat } \\
\mathbf{n = 3 4}\end{array}$ & Nilai p \\
\hline IDU, (\%) & $231 / 300(77,0)$ & $129 / 178(72,5)$ & $23 / 32(71,9)$ & 0,49 \\
Riwayat TB, (\%) & $104 / 305(34,1)$ & $63 / 182(34,6)$ & $13 / 33(39,4)$ & 0,83 \\
Obat TB, (\%) & $30 / 305(9,8)$ & $16 / 182(8,8)$ & $3 / 33(9,1)$ & 0,93 \\
Kandidiasis oral, (\%) & $30 / 275(10,9)$ & $46 / 160(28,8)$ & $17 / 28(60,7)$ & 0,10 \\
Stage WHO & & & 0,70 \\
I (\%) & $42 / 225(18,7)$ & $19 / 134(14,2)$ & $1 / 14(7,1)$ & \\
II (\%) & $19 / 225(8,4)$ & $9 / 134(6,7)$ & $1 / 14(7,1)$ & \\
III (\%) & $84 / 225(37,3)$ & $49 / 134(36,6)$ & $7 / 14(50,0)$ & \\
IV (\%) & $80 / 225(35,6)$ & $57 / 137(42.5)$ & $13 / 33(35,7)$ & \\
\hline
\end{tabular}

Tabel 3 Karakteristik Hasil Laboratorium dan Pengobatan Penderita HIV-AIDS dengan Anemia dan Tanpa Anemia

\begin{tabular}{|c|c|c|c|c|}
\hline Variabel & $\begin{array}{c}\text { Tidak Anemia } \\
\mathrm{n}=\mathbf{3 1 2}\end{array}$ & $\begin{array}{c}\text { Anemia Ringan } \\
\mathrm{n}=\mathbf{1 8 8}\end{array}$ & $\begin{array}{c}\text { Anemia Sedang-Berat } \\
\mathrm{n}=\mathbf{3 4}\end{array}$ & Nilai $\mathbf{p}$ \\
\hline \multicolumn{5}{|l|}{$\overline{\mathrm{ARV}}$} \\
\hline Tanpa (\%) & $130 / 307(42,7)$ & $103 / 184(56,0)$ & $24 / 33(72,7)$ & $<0,001$ \\
\hline Zidovudin, basis (\%) & $104 / 307(33,9)$ & $65 / 184(35,3)$ & $7 / 33(21,2)$ & \\
\hline $\mathrm{d} 4 \mathrm{~T}$, basis $(\%)$ & $69 / 307(22,5)$ & $16 / 184(8,7)$ & $2 / 33 \quad(6,1)$ & \\
\hline Lainnya, (\%) & $2 / 307 \quad(1,3)$ & $0 / 184 \quad(0,0)$ & $(0,0)$ & \\
\hline \multicolumn{5}{|l|}{ Lama ARV } \\
\hline$<1$ bulan $(\%)$ & $4 / 177 \quad(2,3)$ & $9 / 81 \quad(11,1)$ & $2 / 9 \quad 22,2)$ & $<0,001$ \\
\hline $1-6$ bulan $(\%)$ & $9 / 177 \quad(5,1)$ & $18 / 81 \quad(22,2)$ & $1 / 9 \quad(11,1)$ & \\
\hline$>6$ bulan $(\%)$ & $164 / 177(92,7)$ & $54 / 81 \quad(66,7)$ & $6 / 9(66,7)$ & \\
\hline Kotrimoksazol, (\%) & $95 / 301(31,6)$ & $62 / 182(34,1)$ & $11 / 31(35,5)$ & 0,80 \\
\hline \multicolumn{5}{|l|}{$\mathrm{CD} 4$} \\
\hline$>200,(\%)$ & $212 / 308(68,8)$ & $60 / 185(32,4)$ & $12 / 33(36,4)$ & $<0,001$ \\
\hline $101-200,(\%)$ & $48 / 308(15,6)$ & $28 / 185(15,1)$ & $4 / 33(12,1)$ & \\
\hline $51-100$ & $25 / 308 \quad(8,1)$ & $24 / 185(13,0)$ & $4 / 33(12,1)$ & \\
\hline $1-50$ & $23 / 308 \quad(7,5)$ & $73 / 185(39,5)$ & $13 / 33(39,4)$ & \\
\hline \multicolumn{5}{|l|}{ Viral load } \\
\hline$<400$ & $172 / 219(78,5)$ & $51 / 91(56,0)$ & $7 / 12(58,3)$ & $<0,001$ \\
\hline $400-10.000$ & $11 / 219 \quad(5,0)$ & $11 / 91(12,0)$ & $(0,0)$ & \\
\hline$>10.000$ & $36 / 219(16,4)$ & $29 / 91(31,8)$ & $5 / 12(41,6)$ & \\
\hline Viral load, tanpa ARV & 120325 & 281452 & 304368 & 0,11 \\
\hline Median (IQR) & $(15469-365174)$ & $(137957-658567)$ & $(21837-674332)$ & \\
\hline Viral load, ARV $>6$ bulan & $\mathrm{n}=21$ & $\mathrm{n}=25$ & $\mathrm{n}=4$ & \\
\hline$<400 \mathrm{kopi} / \mathrm{mL}, \%$ & $138 / 157(87,9)$ & $43 / 52(82,7)$ & $6 / 6(100,0)$ & 0,35 \\
\hline
\end{tabular}

terjadinya anemia.

Dari Tabel 1, Tabel 2 dan Tabel 3 tampak bahwa variabel karakteristik penderita HIV-AIDS yang berpengaruh terhadap kejadian anemia yaitu BMI, pemberian ARV, CD4, kandidiasis oral dan viral load $(\mathrm{p}<0,001)$.

Dari tabel-tabel tersebut yang mempunyai $\mathrm{p}<0,25$ selanjutnya dilakukan analisis secara simultan dengan analisis regresi logistik ganda. Hasilnya akan terlihat pada Tabel 5.

Pada Tabel 4 menunjukkan bahwa CD4 mempunyai OR paling besar yaitu 8,66 untuk CD4 antara 1-50 dan OR 8,66 untuk CD4 antara 51-100. Sedangkan BMI dan ARV mempunyai OR di bawah 1, berarti keduanya bersifat sebagai protektif.

Hasil perhitungan model regresi logistik untuk hubungan antara OC, ARV, BMI dan CD4 dengan kejadian anemia adalah:

$\ln (\mathrm{y} / 1-\mathrm{y})=-0,437+0,615 *$ OC- $0,132 * \mathrm{ARV}-0,585$ $* \mathrm{BMI}+0,67 * \mathrm{Cd} 4$.

Berdasarkan persamaan regresi logistik ini, dapat 
Tabel 4 Hubungan Berbagai Faktor Risiko dengan Kejadian Anemia pada Penderita HIV-AIDS (Hasil Analisis Multivariabel dengan Regresi Logistik)

\begin{tabular}{|c|c|c|c|c|}
\hline Variabel & Koefisien B & SE (B) & Nilai $p$ & OR $(95 \% \mathrm{CI})$ \\
\hline \multicolumn{5}{|l|}{ BMI } \\
\hline $18,5-22,9$ & $-1,000$ & 0,272 & $<0,001$ & $0,368(0,216-0,627)$ \\
\hline $23,0-24,9$ & $-1,631$ & 0,458 & $<0,001$ & $0,196(0,080-0,400)$ \\
\hline $25,0-29,9$ & $-1,582$ & 0,465 & $<0,001$ & $0,206(0,083-0,511)$ \\
\hline $30+$ & $-1,545$ & 1,164 & 0,184 & $0,499(0,025-9,837)$ \\
\hline CD4 & & & $<0,001$ & \\
\hline $101-200$ & 0,653 & 0,327 & 0,046 & $1,921(1,012-3,648)$ \\
\hline $51-100$ & 1,004 & 0,402 & 0,012 & $2,729(1,242-5,997)$ \\
\hline $1-50$ & 2,159 & 0,345 & $<0,001$ & $8,660(4,407-13,522)$ \\
\hline $\mathrm{ARV}(+)$ & $-0,100$ & 0,249 & 0,687 & $0,905(0,555-1,474)$ \\
\hline Kandidiasis oral & 0,584 & 0,303 & 0,054 & $1,793(0,990-3,248)$ \\
\hline Konstanta & $-0,193$ & & & \\
\hline
\end{tabular}

Tabel 5 Peluang Terjadinya Anemia dari Berbagai Kombinasi Faktor Risiko

\begin{tabular}{ccccc}
\hline Kandidiasis oral & ARV & BMI & CD4 & Peluang (Anemia) \\
\hline- & - & $<18,5$ & $51-100$ & 0,712 \\
- & - & $<18,5$ & 50 & 0,828 \\
- & - & $18,5-22,9$ & $\leq 50$ & 0,729 \\
- & + & $<18,5$ & $\leq 50$ & 0,809 \\
- & + & $18,5-22,9$ & $\leq 50$ & 0,702 \\
+ & - & $<18,5$ & $\leq 50$ & 0,899 \\
+ & - & $18,5-22,9$ & $51-100$ & 0,718 \\
+ & - & $18,5-22,9$ & $\leq 50$ & 0,832 \\
+ & - & $23,0-24,9$ & $\leq 50$ & 0,735 \\
+ & + & $<18,5$ & $\leq 50$ & 0,887 \\
+ & + & $18,5-22,9$ & $\leq 50$ & 0,813 \\
+ & + & $23,0-24,9$ & $\leq 50$ & 0,708 \\
\hline
\end{tabular}

dihitung peluang terjadinya anemia, yaitu dengan menggunakan rumus:

$\mathrm{P}($ Anemia $)=1 /\left(1+\exp -\left(-0,437+0,615^{*} \mathrm{OC}-\right.\right.$ $0,132 * \mathrm{ARV}-0,585 * \mathrm{BMI}+0,67 * \mathrm{Cd} 4)$ dan hasilnya ditunjukkan pada Tabel 5 .

Dari Tabel 5 menunjukkan bahwa peluang terbesar terjadinya anemia pada penderita HIVAIDS adalah kombinasi BMI $<18,5$ dan kandidiasis oral serta tanpa ARV dengan CD4 di bawah $50 \mathrm{sel} / \mathrm{mm}^{3}$. Nilai yang hampir sama yaitu seperti di atas tetapi dengan mendapat ARV. Tampak pula bahwa BMI dan CD4 $\leq 50 \mathrm{sel} / \mathrm{mm}^{3}$ merupakan unsur yang selalu ada sebagai peluang terjadinya anemia.

\section{Pembahasan}

Prevalensi anemia pada penderita HIV-AIDS berkisar antara 1,3\%-95\% tergantung dari stadiumnya, makin tinggi stadium akan makin tinggi prevalensi anemia. Dalam penelitian ini prevalensi anemia adalah 41,6\% (95\% CI: 37,4$45,8 \%$ ) dengan jumlah terbanyak masuk dalam stadium III dan IV. Penelitian anemia pada infeksi HIV-AIDS di Indonesia belum banyak, dan di samping itu definisi anemia yang dipergunakan masih belum seragam, kebanyakan masih tetap memakai patokan hemoglobin $10 \mathrm{~g} / \mathrm{dL}$ sebagai batas anemia, seperti yang dilaporkan oleh Lydia, ${ }^{8}$ Surzamin, ${ }^{9}$ Fauzan dkk. ${ }^{10}$ Efiyanti et al. ${ }^{11}$ Karyadi et al., ${ }^{12}$ serta Karsono dan Muthalib. ${ }^{13}$

Belperio dan Rhew $^{6}$ yang melakukan meta analisis terhadap 31 jurnal yang berhubungan dengan anemia pada infeksi HIV menyimpulkan beberapa hal, antara lain bahwa prevalensi anemia lebih tinggi pada penderita AIDS terutama dengan CD4 rendah dibandingkan yang belum termasuk 
dalam kategori AIDS. Didapatkan juga bahwa $22 \%$ anemia disebabkan oleh obat-obatan.

Subbaraman ${ }^{15}$ di kota Chennai India Selatan antara Januari sampai April 2006 melaporkan prevalensi anemia sebesar $22 \%$, penderita dengan CD4 > $500 \mathrm{sel} / \mathrm{mm}^{3}$, kemudian prevalensinya meningkat menjadi $60 \%$ pada penderita dengan CD4 $<100 \mathrm{sel} / \mathrm{mm}^{3}$. Kemudian peneliti tersebut menyimpulkan bahwa anemia berhubungan dengan supresi imun yang berat pada penderita infeksi HIV.

Pada penelitian di 11 negara di Sub Sahara Afrika, pada wanita yang terinfeksi HIV dengan prevalensi anemia sebesar 56,7\% (SD 12,7), dan rentang antara $33-72 \%$. Penelitian tersebut juga menyebutkan bahwa anemia berhubungan dengan indeks massa tubuh yang rendah. ${ }^{16}$ Penelitian oleh Ramezani et al., ${ }^{17}$ di Iran mendapatkan bahwa anemia ringan-sedang yaitu hemoglobin antara 8$14 \mathrm{~g} / \mathrm{dL}$ terdapat pada $46 \%$ penderita infeksi HIV, akan tetapi tidak mendapatkan perbedaan antara penderita anemia dan tidak anemia dalam hal umur, jenis kelamin, stadium penyakit, jumlah CD4, dan pemberian antiretroviral.

Sullivan dan Buskin ${ }^{18}$ melaporkan prevalensi anemia sebesar $77 \%$ pada satu periode pengamatan terhadap 2.408 penderita infeksi HIV antara tahun 1996-2001. Penderita infeksi HIV dengan CD4 kurang dari $100 \mathrm{sel} / \mathrm{mm}^{3}$, tidak menunjukkan penurunan prevalensi anemia. Ini berarti bahwa meskipun telah ada perkembangan pengobatan infeksi HIV berupa HAART yang dimulai pada tahun 1996, akan tetapi prevalensi anemia tetap tinggi.

Semba et al. ${ }^{19}$ melaporkan hasil pengamatan pada 797 wanita pengidap infeksi HIV dan 389 wanita yang tidak mengidap infeksi HIV, pada pengidap HIV prevalensi anemia adalah $28,1 \%$ sedangkan pada wanita yang tidak mengidap HIV prevalensi anemia adalah $15,1 \%$, perbedaan ini bermakna $(p<0,0001)$.

Anemia sangat prevalen terhadap penderita infeksi HIV yang berhubungan dengan IDU, ${ }^{20}$ akan tetapi pada penelitian ini kejadian anemia yang berhubungan dengan IDU adalah 152/210 atau $72,4 \%$, sedangkan pada kelompok non-IDU kejadian anemia adalah $231 / 300$ atau $77 \%$.

Penelitian oleh Semba et al..$^{19}$ menunjukkan bahwa faktor risiko untuk kejadian anemia adalah wanita keturunan Afrika-Amerika dengan OR 2,15 (95\% CI: 1,73-2,69), umur dengan OR 1,12 (95\% CI: 1,03-1,21, BMI dengan OR 0,96 (95\%
CI: 0,94-0,97), riwayat pneumonia dengan OR 1,41 (95\% CI: 1,20-1,65), kandidiasis oral dengan OR 1,42 (95\% CI: 1,222-1,66), CD4 kurang dari $200 \mathrm{sel} / \mathrm{mm}^{3}$ dengan OR 1,68 (95\% CI: 1,46-1,94), dan demam dengan OR 1,42 (95\% CI: 1,13-1,8).

Penelitian oleh Subbaraman ${ }^{15}$ di India pada 7.069 penderita infeksi HIV menyimpulkan bahwa faktor risiko yang berhubungan dengan anemia adalah CD4 $<100 \mathrm{sel} / \mathrm{mm}^{3}$, indeks massa tubuh yang menunjukkan underweight, wanita, menderita tuberkulosis aktif dan tidak mendapat profilaksis kotrimoksazol.

Hasil penelitian penulis mendapatkan faktor risiko yang penting untuk kejadian anemia adalah $\mathrm{BMI}$ yang rendah, $\mathrm{CD} 4$, kandidiasis oral dan $\mathrm{ARV}$ sebagai faktor protektif. Kandidiasis oral merupakan petunjuk progresivitas penyakit dan berhubungan langsung dengan jumlah CD4. Dalam penelitian penderita yang mempunyai CD4 antara $1-50 \mathrm{sel} / \mathrm{mm}^{3}$ mencapai hampir $40 \%$ berarti dua dari lima penderita datang pada stadium lanjut.

Kesimpulan dari penelitian ini adalah bahwa prevalensi anemia pada HIV-AIDS cukup tinggi, dengan anemia pada penyakit kronik sebagai jenis anemia yang terutama didapat. Faktor risiko yang berperan dalam anemia adalah BMI yang rendah, CD4 antara $150 / \mathrm{mm}^{3}$ dan kandidiasis oral serta ARV sebagai faktor protektif. Pengelolaan anemia pada penderita HIV-AIDS harus dilakukan dengan sebaik-baiknya untuk mengurangi angka kematian pada penderita HIV-AIDS. Perlu adanya studi kohor untuk melihat segala aspek penderita HIV-AIDS, seperti kematian jangka pendek, efek samping obat antiretroviral, adanya virologic failure, maupun kematian jangka panjang .

\section{Daftar Pustaka}

1. UNAIDS. AIDS epidemic update: global sum-mary of the AIDS epidemic 2007. Geneva: WHO Library Cataloguing Data; 2007.

2. UNAIDS. The global HIV challenge, 2008. Report on the global AIDS epidemic. Geneva: WHO Library Cataloguing Data; 2008.

3. Statistik kasus HIV/AIDS di Indonesia. Jakarta: Ditjen PPM \& PL Depkes RI; Desember 2008

4. WHO. Review of the health sector response to HIV and AIDS in Indonesia 2007. New Delhi: WHO Library Cataloguing data. World Health Organization, Regional Office for South-East Asia; 2007.

5. Laporan pengidap infeksi HIV dan kasus AIDS s.d 31 Desember 2008 di Provinsi Jawa Barat dari tahun 1989 sd Deptember 2008. Bandung: P2M Dinkes Provinsi 
Jawa Barat; 2009.

6. Belperio PS, Rhew DC. Prevalence and outcomes of anemia in individuals with human immunodeficiency virus: a systematic review of the literature. Am J Med. 2004 April 5;16(7A): 27-43.

7. Volberding PA, Levine AM, Dieterich D, Mildvan D, Mitsuyasu R, Saag M. Anemia in HIV infection: clinical impact and evidence-based management strategies. Clin Infect Dis. 2004 May 15;38:1454-63.

8. Lydia A. Hitung limfosit total sebagai prediktor hitung CD4 pada penderita AIDS. (Tesis) Jakarta: Bagian Penyakit Dalam FKUI; 1996.

9. Surzamin M. Hitung limfosit total sebagai indikasi memulai terapi antiretroviral pada pasien HIV/AIDS. (Tesis) Jakarta: Bagian Ilmu Penyakit Dalam FKUI; 2002.

10. Fauzan A, Djauzi S, Djoerban Z, Sukmana N. Proporsi respon pengobatan antiretroviral selama enam bulan pada penderita HIV. Jakarta: Balai Penerbit FKUI; 2005.

11. Efiyanti C, Mayasari F, Bhakti SK, Dharma I, Harijono L, Kapojos AL, et al. Characteristic of HIV positive adult patients at Royal Taruma Hospital Jakarta, Indonesia. Clinical Research Meeting of The Indonesia Association of Physicians in AIDS Care, Faculty of Medicine University of Indonesia, Jakarta, $11-12^{\text {th }}$ April, 2008.

12. Karyadi TH, Yunihastuti E, Sukmana N, Djoerban Z. Anemia in patients HIV with zidovudine therapy. Scientific meeting of the Indonesian Association of Physicians in AIDS Care, Dharmais Cancer Hospital, Jakarta, 26-28 $8^{\text {th }}$ November, 2005.

13. Karsono B, Muthalib A. AZT induced anemia in HIV infected persons. Scientific Meeting of the Indonesian Association of Physicians in AIDS Care, Dharmais Cancer Hospital, Jakarta, 26-28 ${ }^{\text {th }}$ November, 2005.

14. Glassman AB. Anemia, diagnosis and clinical Considerations. Dalam: Harmening DM, penyunting. Clinical hematology and fundamentals of hemostasis. Edisi ke-4. Philadelphia: F.A,Davis Company; 2002. hlm. 74-83.

15. Subbaraman R. Anemia among HIV-infected in South India. New Haven: The Yale University of Medicine; 2007.

16. Bradley EK, Mishra V. HIV and nutrition among women in Sub-Saharan Africa. USAID. 2008. September.

17. Ramezani A, Aghakhan A, Sharif M Z, Banifazi M, Eslamifar A, Velayati A A. Anemia prevalence and related factors in HIV-infected patients: a cohort study. Iranian J Phathol. 2008;3(3):128-8.

18. Sullivan P, Buskin S. Early diagnosis and appro-priate treatment of HIV-related anemia important to survival of the HIV-positive. The $2^{\text {nd }}$ International AIDS Society Conference on HIV Pathogenesis and Treatment. July $14^{\text {th }}$, Poster 1154,2003

19. Semba RD, Shah N, Klein RS, Mayer KH, Schuman P, Vlahov D, et al. Prevalence and cumulative incidence of and risk factors for anemiaa in a multicenter cohort study of human immunodeficiency virus-infected anduninfected women. Clin Infect Dis. 2002 Jan 15;34: 260-6.

20. Sullivan PS, Hanson DL, Chu SY, Jones JL, Ward JW. Epidemiology of anemia in human immuno-deficiency virus (HIV)-infected person. Blood. 1998 Jan 1; 91(1): 301-8. 